\title{
MODEL KURIKULUM PENDIDIKAN LAYANAN KHUSUS PENDIDIKAN NON FORMAL UNTUK DAERAH KONFLIK
}

\section{Kamin Sumardi}

Abstrak. Curriculum is one important component in education, as specially in learning process. Curriculum must support all the student need, because of it, we need a special curriculum. Every conflict has a different characteristic, but the effect on the child education has the same meaning. Because of that, we have to arrange one of curriculum development and the evaluation more specific by using a special service especially in non forma education. Special service education in non formal education (PLK-PNF) for conflict area, which has a base differentiation in learning process. This special service education has a double mission, for education and ti handle the side effect of conflict as physically and also psychologist.

Kata Kunci : Daerah Konflik, Layanan Khusus, Pendidikan Non Formal 
ISSN: 1829-6750 Inovasi Kurikulum, Februari 2008, Thn. 5. Vol 5 Nomor: 1

\section{Pendahuluan}

Kurikulum merupakan suatu rancangan pendidikan yang merangkum semua pengalaman belajar anak di sekolah.

Kedalamnya terintegrasi dengan filsafat, nilai-nilai, pengetahuan, keterampilan dan perbuatan pendidikan.

Kurikulum disusun oleh para ahli pendidikan, ahli bidang ilmu, pendidik, pejabat pendidikan, serta unsur-unsur masyarakat lainnya. Rancangan ini disusun dengan maksud memberi pedoman bagi proses pembimbingan perkembangan anak didik, mencapai tujuan yang dicitacitakan anak didik, keluarga maupun masyarakat.

Esensi dari pengembangan kurikulum adalah proses identifikasi, analisis, sitesis, evaluasi, pengambilan keputusan dan kreasi elemenelemen kurikulum. Agar dalam proses pengembangan kurikulum itu dapat berjalan secara efektif dan efisien, maka para pengembang kurikulum dalam bekerjanya harus memperhatikan prinsipprinsip pengembangan kurikulum. Dengan merujuk pada pengembangan kurikulum, para pengembang kurikulum akan dapat bekerja dengan terarah dan hasil yang dapat dipertanggungjawabkan.

Mengacu pada paparan di atas model kurikulum ini diarahkan untuk membantu penyelenggara dan pengelola pendidikan non formal dalam merancang kurikulum. Khususnya pada proses pelaksanaan kegiatan pembelajaran yang memenuhi kebutuhan dan karakteristik perkembangan warga belajar daerah konflik. Melalui upaya ini diharapkan akan memberikan pencerahan kepada tutor di daerah konflik. Selan itu model ini dapat digunakan untuk mengembangkan variasi proses pembelajaran yang dapat memberikan kesempatan anak memperoleh sejumlah 
ISSN: 1829-6750 Inovasi Kurikulum, Februari 2008, Thn. 5. Vol 5 Nomor: 1

pengalaman belajar secara aktif (active learning), kreatif (creative learning) dan menyenangkan (fun). Pendekatan yang dapat digunakan dalam pembelajaran layanan khusus pendidikan non formal (PLKPNF), yaitu:

1. Pendekatan Induktif adalah pendekatan yang membangun pengetahuan melalui kejadian atau fenomena empirik dengan menekankan pada belajar pada pengalaman langsung.

2. Pendekatan Tematik adalah pendekatan yang mengorganisasikan pengalaman- pengalaman dan mendorong terjadinya pengalaman belajar yang meluas tidak hanya tersekat-sekat oleh batasan pokok bahasan, sehingga dapat mengaktifkan peserta didik dan menumbuhkan kerjasama.

3. Pendekatan Konstruktif adalah pendekatan yang menumbuhkan pengakuan bahwa setiap peserta didik mempunyai pandangan sendiri terhadap "dunia" dan alam sekitarnya berdasarkan pengalaman individu dalam menghadapi dan menyelesaikan situasi yang tidak tentu. Pembelajaran konstruktif dilaksanakan melalui pandangan individual peserta didik untuk membangun makna.

4. Pendekatan Partisipatif Andragogis; adalah pendekatan yang membantu menumbuhkan kerjasama dalam menemukan dan menggunakan hasil-hasil temuannya yang berkaitan dengan lingkungan sosial, situasi pendidikan yang dapat merangsang pertumbuhan dan kesehatan individu, maupun masyarakat.

5. Berbasis Lingkungan adalah pendekatan yang 
ISSN: 1829-6750 Inovasi Kurikulum, Februari 2008, Thn. 5. Vol 5 Nomor: 1

meningkatkan relevansi dan kebermanfaatan pembelajaran bagi peserta didik sesuai potensi dan kebutuhan lokal.

\section{Metode Pembelajaran}

Dengan tetap memperhatikan aspek psikologi dan sosial kelompok masyarakat yang berbeda-beda, dan berdasarkan pendekatanpendekatan tersebut di atas, secara garis besar proses pembelajaran dilakukan melalui beberapa metode berikut:

1. Metode Kooperatif; menggalakkan peserta didik yang mempunyai berbagai kebolehan berinteraksi dan bekerja sama untuk menguasai sesuatu konsep atau keterampilan bukan saja untuk diri sendiri tetapi juga untuk rekan rekan yang lain, serta memotivasi semua peserta didik.

2. Metode Interaktif; suatu kaidah yang melibatkan interaksi antara tutor dan peserta didik, antar peserta didik, peserta didik dengan komputer, atau peserta didik dengan lingkungannya.

3. Metode Eksperimen; proses pembelajaran dengan menjalankan kajian atau penyiasatan tentang suatu fenomena yang berlaku dalam alam sekitar.

4. Tutorial; kependidikan menerangkan pelajaran secara interaktif dengan membuka peluang kepada peserta didik untuk bertanya.

5. Diskusi; tenaga kependidikan menugaskan peserta didik untuk mendiskusikan, isu tertentu yang berkaitan dengan tema pelajaran dan dalam waktu yang sama tenaga kependidikan membimbing dan memberikan kata putus. 
ISSN: 1829-6750 Inovasi Kurikulum, Februari 2008, Thn. 5. Vol 5 Nomor: 1

6. Penugasan; tenaga kependidikan

memberikan tugas kepada peserta didik, baik secara individual

maupun kelompok, tugas-tugas yang berkaitan dengan pelajaran.

7. Praktek; kependidikan menerangkan memberikan tentang tenaga membuat keterampilan tertentu, kemudian diikuti dan diterapkan oleh peserta didik.

8. Belajar mandiri; proses belajar di luar jam pelajaran formal di mana peserta didik mempelajari pelajaran atau mempraktekkan keterampilan suatu bantuan kawan ataupun orang lain.

9. Demonstrasi; belajar proses menggunakan peragaan.

10. Observasi; proses belajar dengan memperhatikan dan menganalisa objek pembelajaran.

11. Simulasi; proses belajar dengan bermain peran atau menggunakan alat peraga/ bukan alat sesungguhnya.

12. Studi kasus; proses belajar untuk mengembangkan kemampuan memecahkan masalah.

Untuk dapat mengembangkan suatu model kurikulum yang sesuai dengan kondisi daerah konflik, perlu dilakukan langkah-langkah yang disesuaikan dengan tingkat perkembangan peserta didik, dan karakteristik daerah konflik. Langkah dalam pembuatan kurikulum ini secara umum mengikuti rambu-rambu yang sudah ada yang dikeluarkan oleh BSNP. Hanya saja konteknya disesuaikan dengan kondisi dan karakteristik masyarakat dan karakteristik konflik itu sendiri. Penekanan dalam penyusunan kurikulum di 
ISSN: 1829-6750 Inovasi Kurikulum, Februari 2008, Thn. 5. Vol 5 Nomor: 1

daerah konflik yang harus dilakukan oleh seluruh stake holder yaitu mempunyai berbedaan yang lebih jelas, (sesuai dengan acuan yang dibuat Ditjen PNFI), diantaranya:

1. Pendekatan Tematik

Untuk warga belajar kesetaraan menggunakan pendekatan tematik.

Pembelajaan tematik adalah pembelajaran tepadu yang menggunakan tema untuk mengaitkan beberapa mata pelajaran sehingga dapat memberikan pengalaman bermakna kepada peserta didik. Tema adalah pokok pikiran atau gagasan pokok yang menjadi pokok pembicaraan. Dengan tema diharapkan

memberikan akan keuntungan, di antaranya:

a. Peserta didik mudah memusatkan perhatian pada suatu tema tertentu,

b. Peserta didik mampu mempelajari pengetahuan dan mengembangkan berbagai kompetensi dasar antar matapelajaran dalam tema yang sama;

c. Pemahaman terhadap materi pelajaran lebih mendalam dan berkesan;

d. Kompetensi dasar dapat dikembangkan lebih baik dengan mengkaitkan matapelajaran lain dengan pengalaman pribadi peserta didik;

e. Peserta didik mampu lebih merasakan manfaat dan makna belajar karena materi disajikan dalam konteks tema yang jelas;

f. Peserta didik lebih bergairah belajar karena dapat berkomunikasi dalam situasi nyata, untuk mengembangkan suatu kemampuan dalam satu mata pelajaran sekaligus mempelajari

matapelajaran lain;

g. Guru dapat menghemat waktu karena mata pelajaran yang disajikan secara tematik dapat dipersiapkaan sekaligus dan diberikan dalam dua atau tiga pertemuan, 
ISSN: 1829-6750 Inovasi Kurikulum, Februari 2008, Thn. 5. Vol 5 Nomor: 1

waktu selebihnya dapat digunakan untuk kegiatan remedial, pemantapan, atau pengayaan

2. Karakteristik Pembelajaran Terpadu Bentuk Tematik

Sebagai suatu model pembelajaran di sekolah dasar, pembelajaran tematik memiliki karakteristikkarakteristik sebagai berikut:

1. Pembelajaran tematik berpusat pada peserta didik (student centered), hal ini sesuai dengan pendekatan belajar modern yang lebih banyak menempatkan peserta didik sebagai subjek belajar sedangkan guru lebih banyak berperan sebagai fasilitator yaitu memberikan kemudahankemudahan kepada peserta didik untuk melakukan aktivitas belajar.

2. Pembelajaran tematik dapat memberikan pengalaman langsung kepada peserta didik (direct experiences).
Dengan pengalaman langsung ini, peserta didik dihadapkan pada sesuatu yang nyata (konkrit) sebagai dasar untuk memahami hal-hal yang lebih abstrak. Dalam pembelajaran tematik pemisahan antar mata pelajaran menjadi tidak begitu jelas.

3. Fokus pembelajaran diarahkan kepada pembahasan tema-tema yang paling dekat berkaitan dengan kehidupan peserta didik.

4. Pembelajaran tematik menyajikan konsepkonsep dari berbagai mata pelajaran dalam suatu proses pembelajaran. Dengan demikian, Peserta didik mampu memahami konsep-konsep tersebut secara utuh. Hal ini diperlukan untuk membantu peserta didik dalam memecahkan masalah-masalah yang dihadapi dalam kehidupan sehari-hari. 
ISSN: 1829-6750 Inovasi Kurikulum, Februari 2008, Thn. 5. Vol 5 Nomor: 1

5. Pembelajaran tematik bersifat luwes (fleksibel) dimana guru dapat mengaitkan bahan ajar dari satu mata pelajaran dengan mata pelajaran yang lainnya, bahkan mengaitkannya dengan kehidupan peserta didik dan keadaan lingkungan dimana sekolah dan peserta didik berada.

\section{Landasan Daerah Konflik \\ LPK-PNF}

Landasan filosofis dalam pembelajaran tematik sangat dipengaruhi oleh tiga aliran filsafat yaitu:

progresivisme,

konstruktivisme, dan humanisme.

1. Aliran progresivisme memandang proses pembelajaran perlu ditekankan pada pembentukan kreatifitas, pemberian sejumlah kegiatan, suasana yang alamiah (natural), dan memperhatikan pengalaman peserta didik.
2. Aliran konstruktivisme melihat pengalaman langsung peserta didik (direct experiences) sebagai kunci dalam pembelajaran. Menurut aliran ini, pengetahuan adalah hasil konstruksi atau bentukan manusia. Manusia mengkonstruksi pengetahuannya melalui interaksi dengan obyek, fenomena, pengalaman dan lingkungannya. Pengetahuan tidak dapat ditransfer begitu saja dari seorang guru kepada anak, tetapi harus diinterpretasikan sendiri oleh masing-masing peserta didik. Pengetahuan bukan sesuatu yang sudah jadi, melainkan suatu proses yang berkembang terus menerus. Keaktifan peserta didik yang diwujudkan oleh rasa ingin tahunya sangat berperan dalam perkembangan pengetahuannya. 
ISSN: 1829-6750 Inovasi Kurikulum, Februari 2008, Thn. 5. Vol 5 Nomor: 1

3. Aliran humanisme melihat peserta didik dari segi

keunikan/ kekhasannya, potensinya, dan motivasi yang dimilikinya.

Landasan psikologis dalam pembelajaran tematik terutama berkaitan dengan psikologi perkembangan peserta didik dan psikologi belajar.

Psikologi perkembangan diperlukan terutama dalam menentukan isi/materi

pembelajaran tematik yang diberikan kepada peserta didik agar tingkat keluasan dan kedalamannya sesuai dengan tahap perkembangan peserta didik. Psikologi belajar memberikan kontribusi dalam hal bagaimana isi/materi pembelajaran tematik tersebut disampaikan kepada peserta didik dan bagaimana pula peserta didik harus mempelajarinya.

Landasan yuridis dalam pembelajaran tematik berkaitan dengan berbagai kebijakan atau peraturan yang mendukung pelaksanaan pembelajaran tematik di sekolah dasar. Landasan yuridis tersebut adalah UU No. 23 Tahun 2002 tentang Perlindungan Anak yang menyatakan bahwa setiap anak berhak memperoleh pendidikan dan pengajaran dalam rangka pengembangan pribadinya dan tingkat kecerdasannya sesuai dengan minat dan bakatnya (pasal 9). UU No. 20 Tahun 2003 tentang Sistem Pendidikan Nasional menyatakan bahwa setiap peserta didik pada setiap satuan pendidikan berhak mendapatkan pelayanan pendidikan sesuai dengan bakat, minat, dan kemampuannya (Bab V Pasal 1-b).

Pendekanan

pada pembelajaran tematik menggunakan prinsip belajar sambil bermain dan menyenangkan yang mampu meningkatkan pemahaman perbedaan (etnis, agama, keyakinan), 
ISSN: 1829-6750 Inovasi Kurikulum, Februari 2008, Thn. 5. Vol 5 Nomor: 1

solidaritas warga belajar, meningkatkan rasa toleransi yang disesuaikan dengan karakteristik daerah konflik tanpa mengurangi kompetensi dasar yang ada pada standar isi .Dalam menentukan tema PKBM dapat memilih tema-tema yang sesuai dengan kondisi lingkungan, sosial dan budaya setempat.

\section{Strategi Pembelajaran PLK-PNF Daerah Konflik}

1. Menggunakan basis pendidikan kecakapan hidup (life skill) dengan menggunakan pendekatan mata pelajaran. Penekanan pada mata pelajaran diusahakan mampu meningkatkan rasa solidaritas dan toleran warga belajar. Pendidikan kecakapan hidup hendaknya menjadi prioritas sekolah, karena tingkat putus sekolah dan interaksi sosial sangat tinggi di daerah konflik. Untuk itu diperlukan suatu keterampilan khusus yang dapat menunjang eksistensi mereka dalam kehidupan bermasyarakat seperti : Kerajinan ukiran kayu, rotan menjahit, tenun tradisional, anyaman dsb. Yang sifatnya dapat menjadikan bekal hidup mereka dalam masyarakat. Aspek kecakapan hidup yang dikembangkan meliputi; kecakapan pribadi/personal, kecakapan social, kecakapan akademik dan vocasional.

2. Muatan lokal. Muatan lokal wajib yang paling cocok untuk daerah konflik adalah, karena di daerah.

3. Pengembangan diri. Pengembangan diri diarahkan kepada pembinaan anak yang memiliki kemampuan, keterampilan, kreatifitas dan kesiapan untuk melanjutkan ke jenjang 
ISSN: 1829-6750 Inovasi Kurikulum, Februari 2008, Thn. 5. Vol 5 Nomor: 1

pendidikan yang lebih tinggi dan siap untuk menghadapi persaingan di era globalisasi.

4. Pembiasaan. Pembiasaan ditekankan kepada kegiatan yang dapat meningkatkan proses pembentukan akhlaq mulia sehingga anak didik mempunyai daya penangkal dalam menghadapi ekses negative dari proses akulturasi budaya di perbatasan Negara. Pada umumnya kegiatan pembiasaan dilakukan dengan cara spontan, rutin, keteladanan dan terprogram.

5. Ekstra kurikuler. Ekstra kurikuler hendaknya memilih kegiatan yang dapat meningkatkan rasa solidaritas

nasionalisme dan belajar yang sesuai dengan budaya khas daerah (konflik).

\section{Rambu-Rambu}

Penyusunan KTSP di Daerah Konflik

Pendahuluan
A. Latar belakang

Berisikan tentang penggambaran profil sekolah, letak geografis, dan alasan kenapa harus menyusun kurikulum.

B. Landasan Hukum Berisikan landasan hukum yang digunakan dalam menyusun kurikulum

C. Tujuan penyusunan kurikulum Memuat tujuan-tujuan yang melandasi perlunya pembuatan kurikulum

D. Prinsip pengembangan kurikulum

Pengembangan kurikulum ini berdasarkan prinsip-prinsip sebagai berikut:

1. Berpusat pada potensi, perkembangan, kebutuhan, dan kepentingan peserta didik dan lingkungannya.

2. Beragam dan terpadu. 
ISSN: 1829-6750 Inovasi Kurikulum, Februari 2008, Thn. 5. Vol 5 Nomor: 1
3. Tanggap terhadap perkembangan ilmu pengetahuan, teknologi dan seni.

4. Relevan dengan kebutuhan kehidupan.

5. Menyeluruh dan berkesinambungan.

6. Belajar sepanjang hayat.

7. Seimbang antara kepentingan nasional dan kepentingan daerah.

8. Meningkatkan rasa kebangsaan dan cinta tanah air peserta didik.

Tujuan Pendidikan
A. Tujuan umum

Berisikan tujuan umum pendidikan secara keseluruhan yang harus dicapai oleh satuan pendidikan.

B. Tujuan khusus

Berisikan sejumlah tujuan-tujuan yang akan dicapai oleh sekolah secara periodik dengan landasan sebagai barikut:

1. Berorientasi ke depan.
2. Dikembangkan bersama oleh seluruh warga sekolah.

3. Merupakan perpaduan antara langkah strategis dan sesuatu yang dicita-citakan.

4. Dinyatakan dalam kalimat yang padat bermakna.

5. Dapat dijabarkan ke dalam tujuan dan indikator keberhasilannya.

6. Berbasis nilai.

7. Membumi (kontekstual)

Struktur dan Muatan Kurikulum

A. Struktur kurikulum

Mata pelajaran yang harus ada dalam struktur kurikulum adalah; pendidikan agama, kewarganegaraan, bahasa indonesia, matematika, ilmu pengetahuan alam, ilmu pengetahuan sosial, seni budaya dan keterampilan, pendidikan jasmani dan olahraga. 
ISSN: 1829-6750 Inovasi Kurikulum, Februari 2008, Thn. 5. Vol 5 Nomor: 1

B. Muatan lokal

Muatan lokal merupakan kegiatan kurikuler untuk mengembangkan

kompetensi

yang

disesuaikan dengan ciri khas dan potensi daerah, termasuk keunggulan daerah, yang materinya tidak dapat dikelompokkan ke dalam mata pelajaran yang ada. Substansi mata pelajaran muatan lokal ditentukan oleh satuan pendidikan disesuaikan dengan karakteristik daerah masing-masing. Muatan lokal merupakan bagian dari struktur dan muatan kurikulum yang terdapat pada standar isi di dalam kurikulum tingkat satuan pendidikan. Keberadaan mata pelajaran muatan lokal merupakan bentuk penyelenggaraan pendidikan yang tidak terpusat, sebagai upaya agar penyelenggaraan pendidikan di masingmasing daerah lebih meningkat relevansinya terhadap keadaan dan kebutuhan daerah yang bersangkutan. Hal ini sejalan dengan upaya peningkatan mutu pendidikan nasional sehingga keberadaan mata pelajaran muatan lokal mendukung dan melengkapi mata pelajaran yang lain. Muatan lokal merupakan mata pelajaran, sehingga satuan pendidikan harus mengembangkan standar kompetensi dan kompetensi dasar untuk setiap jenis muatan lokal yang diselenggarakan. Satuan pendidikan dapat menyelenggarakan satu mata pelajaran muatan lokal setiap semester. Ini berarti bahwa dalam satu tahun satuan pendidikan dapat menyelenggarakan dua mata pelajaran muatan lokal. Pelaksanaan pembelajaran muatan lokal dapat dilaksanakan 
ISSN: 1829-6750 Inovasi Kurikulum, Februari 2008, Thn. 5. Vol 5 Nomor: 1

secara berkesinambungan sesuai dengan kompetensi yang dicapai.

C. Pengembangan diri

Pengembagan diri adalah kegiatan yang dilakukan di luar jam belajar efektif yang harus disesuaikan dengan kondisi dan situasi sekolah, tujuannya adalah untuk mengembangkan potensi diri, minat, bakat peserta didik agar mampu mengaktualisasikan diri melalui kegiatan ekstra kurikuler.
D. Pembiasaan

Merupakan proses pembentukan akhlak dan penanaman/ pengamalan ajaran agama serta budi pekerti. Pada umumnya kegiatan pembiasaan ini terbagi atas : spontan, rutin, teladan dan terprogram.

E. Pengaturan beban belajar Beban belajar yang digunakan ialah sistem paket sebagai mana tertera dalam struktur kurikulum yaitu:

\begin{tabular}{|c|c|c|c|c|}
\hline Kelas & $\begin{array}{c}\text { Satuan Jam } \\
\text { Pembelajaran } \\
\text { /menit }\end{array}$ & $\begin{array}{c}\text { Jumlah Jam } \\
\text { per minggu }\end{array}$ & $\begin{array}{c}\text { Minggu } \\
\text { Efektif }\end{array}$ & Waktu \\
\hline I & 35 & 26 & 40 & 1.040 \\
\hline II & 35 & 27 & 40 & 1.080 \\
\hline III & 35 & 28 & 40 & 1.120 \\
\hline IV & 35 & 36 & 40 & 1.440 \\
\hline V & 35 & 36 & 40 & 1.440 \\
\hline VI & 35 & 36 & 40 & 1.440 \\
\hline
\end{tabular}


ISSN: 1829-6750 Inovasi Kurikulum, Februari 2008, Thn. 5. Vol 5 Nomor: 1

Pengaturan alokasi waktu untuk setiap mata pelajaran yang terdapat pada semester ganjil dan genap dalam satu tahun ajaran dapat dilakukan secara fleksibel dengan jumlah beban belajar yang tetap. Satuan pendidikan dimungkinkan menambah maksimum empat jam pembelajaran per minggu secara keseluruhan. Pemanfaatan jam pembelajaran tambahan

mempertimbangkan kebutuhan peserta didik dalam mencapai kompetensi, di samping dimanfaatkan untuk mata pelajaran lain yang dianggap penting dan tidak terdapat di dalam struktur kurikulum yang tercantum di dalam standar isi.

F. Ketuntasan belajar minimal

Ketuntasan belajar setiap indikator yang telah ditetapkan dalam suatu kompetensi dasar berkisar antara 0-100\%. Kriteria ideal ketuntasan untuk masing-masing indikator $75 \%$. Satuan pendidikan harus menentukan kriteria ketuntasan minimal dengan

mempertimbangkan

tingkat kemampuan ratarata peserta didik serta kemampuan sumber daya pendukung dalam penyelenggaraan pembelajaran. Satuan pendidikan diharapkan meningkatkan kriteria ketuntasan belajar secara terus menerus untuk mencapai kriteria ketuntasan ideal.

G. Kenaikan kelas dan kelulusan

1. Kenaikan kelas:

Kenaikan kelas dilaksanakan pada setiap akhir tahun pelajaran. Kriteria kenaikan kelas sebagai berikut: 
ISSN: 1829-6750 Inovasi Kurikulum, Februari 2008, Thn. 5. Vol 5 Nomor: 1

a) Siswa dinyatakan naik kelas setelah menyelesaikan seluruh program pembelajaran pada dua semester di kelas yang diikuti.

b) Tidak terdapat nilai di bawah standar ketuntasan belajar minimal (SKBM) tiga mata pelajaran yang meliputi:

- Pendidikan agama islam

- $\quad$ Pendidikan kewarganegaraan

- Bahasa indonesia

c) Memiliki nilai minimal baik $(6,5)$ untuk aspek kepribadian pada semester yang diikuti.

2. Kriteria kelulusan:

Mengacu standar penilaian yang dikembangkan oleh bsnp pp 19/2005 pasal 72 ayat 1 dan standar penilaian sekolah, peserta didik dinyatakan lulus apabila:

a. Menyelesaikan seluruh program pembelajaran. b. Memperoleh nilai minimal baik untuk seluruh kelompok mata pelajaran: agama islam, kewarganegaraan, matematika, ipa, ips, bahasa indonesia, seni budaya dan keterampilan, penjas orkes, bahasa inggris, dan keterampilan komputer. Sesuai dengan standar kelulusan minimal.

c. Lulus ujian sekolah

d. Lulus ujian nasional

H. Pendidikan Kecakapan Hidup

Pendidikan kecakapan hidup dalam pengembangannya terintegrasi dengan semua mata pelajaran. Aspek kecakapan hidup yang dikembangkan meliputi; kecakapan pribadi, kecakapan sosial, kecakapan akademik dan kecakapan vokasional. Rincian aspek kecakapan hidup

yang 
ISSN: 1829-6750 Inovasi Kurikulum, Februari 2008, Thn. 5. Vol 5 Nomor: 1

dikembangkan antara lain:

1. Kecakapan pribadi (personal).

2. Kecakapan sosial

3. Kecakapan akademik Dengan prosentasi kegiatan lebih menekankan kepada kecakapan sosial, karena intensitas interaksi dengan warga pribumi dan warga asing sangat tinggi.

I. Pendidikan berbasis keunggulan global dan lokal

Pendidikan berbasis keunggulan lokal dan global adalah pendidikan yang memanfaatkan keunggulan lokal dan kebutuhan daya saing global dalam aspek ekonomi, budaya, bahasa, teknologi informasi dan komunikasi, ekologi, dan lain-lain, yang semuanya bermanfaat

bagi pengembangan

kompetensi peserta didik.

Kurikulum untuk semua tingkat satuan pendidikan dapat memasukkan pendidikan berbasis keunggulan lokal dan global. Pendidikan berbasis keunggulan lokal dan global dapat merupakan bagian dari semua mata pelajaran dan juga dapat menjadi mata pelajaran muatan lokal. Pendidikan berbasis keunggulan lokal dapat diperoleh peserta didik dari satuan pendidikan formal lain dan/atau nonformal yang sudah memperoleh akreditasi.

J. Kalender pendidikan

Satuan pendidikan dasar dan menengah dapat menyusun kalender pendidikan sesuai dengan kebutuhan daerah, karakteristik sekolah, kebutuhan peserta didik dan masyarakat, dengan memperhatikan kalender 
ISSN: 1829-6750 Inovasi Kurikulum, Februari 2008, Thn. 5. Vol 5 Nomor: 1

pendidikan sebagaimana yang dimuat dalam standar isi.

\section{Daftar Pustaka}

Ansyar, M. (1989). DasarDasar Pengembangan Kurikulum. Jakarta: Depdikbud Dirjen Dikti P2LPTK.

Kaber,

A. (1988).

Pengembangan Kurikulum. Jakarta: Depdikbud Dirjen Dikti P2LPTK.

McNeil, John D. (1977).

Curriculum: A

Comprehensive

Introduction. Boston: Little Brown and Company.

Oliva, Peter F. (992).

Developing the

Curriculum. Boston: Little Brown and Company.

Saylor, JG. et al. (1981).

Curriculum Planning for Better Teaching and Learning. New York: Holt, Rinehart and Winston.

Smith, OB., Stanley, WO., dan Shores, JH. (1957).

Fundamental of

Curriculum Development.
New York: Harcourt Brace and World.

Sukmadinata, N. Sy. (2000). Pengembangan Kurikulum: Teori dan Praktek. Bandung: Remaja Rosdakarya.

Tim Dosen MKDK. (2006). Kurikulum dan Pembelajaran. Bandung: Jurusan KTP FIP Universitas Pendidikan Indonesia.

Tyler, Ralph W. (1975). Basic Principles of Curriculum and Instruction. Chicago: The University of Chicago Press.

Zais, Robert S. (1976). Curriculum: Principles and Foundations. New York: Harper and Row Publisher. 